\title{
Analysis of impact on tissue activity during COVID-19 outbreak: a survey of 8 banks in Spain
}

\author{
Rafael Villalba $(1) \cdot$ Silvia Santos • María José Martinez $\cdot$ Macarena Díaz • \\ Marta Pevida - Arantxa Cemborain - Celia Casares - Vicente Mirabet
}

Received: 15 May 2020/ Accepted: 28 July 2020/Published online: 15 October 2020

(C) Springer Nature B.V. 2020

\begin{abstract}
On March 19 World Health Organization declare the pandemic situation by outbreak coronavirus disease 2019 in the world. The pressure on the health care system has been very high in several countries. Spanish National Transplant Organization (ONT) have made many efforts in maintaining transplantation activity. Although the impact of the pandemic on organ activity has been analysed, to date, less data exist regarding the impact on tissue activity. The aim of this study has been the evaluation
\end{abstract}

R. Villalba $(\square)$

Center for Blood Transfusion, Tissue and Cells, Avda.

San Alberto Magno s/n, 14004 Córdoba, Spain

e-mail: rafael.villalba.sspa@juntadeandalucia.es

S. Santos

Center for Blood Transfusion and Tissue Bank of Basque Country, Galdakao, Spain

M. J. Martinez

Blood and Tissue Bank of Aragon, Zaragoza, Spain

M. Díaz

Center for Blood Transfusion, Tissue and Cells, Málaga, Spain

M. Pevida

Blood Transfusion Center and Tissue Bank of Asturias, Oviedo, Spain

A. Cemborain

Blood Transfusion Center and Tissue Bank of Navarra,

Pamplona, Spain of the possible impact on the procurement, processing and distribution of tissues during the peak period of the pandemic COVID-19 in Spain. For this study, a multicentre analysis has been made with a survey of the tissue banks in Spain, during the period March 1 to April 30, 2020. Our data suggest that the impact of coronavirus in Spain has affected dramatically tissue donation but with a moderate effect on stored tissues such as bone, valves, vessels or skin. Tissue banks should prepare if future next pandemic waves surges

\author{
C. Casares \\ Tissue Bank of Getafe Hospital, Madrid, Spain \\ V. Mirabet \\ Center for Blood Transfusion and Tissue Bank of \\ Valencian Community, Valencia, Spain
}


so that tissue provision is guaranteed both in urgent and elective surgeries.

Keywords Tissue bank - COVID-19 · Spain · Pandemic period $\cdot$ Outbreak

\section{Introduction}

At the end of December 2019, Chinese public health authorities reported several cases of acute respiratory syndrome in Wuhan City, Hubei province, China (Chen et al. 2020). Chinese scientists soon identified a novel coronavirus as the main causative agent (Zhun et al. 2020). The disease is now referred to as coronavirus disease 2019 (COVID-19), and the causative virus is called severe acute respiratory syndrome coronavirus 2 (SARS-CoV-2) (Zhou et al. 2020), it is a new strain of coronavirus that has not been previously identified in humans. COVID-19 is an illness characterised by respiratory symptoms, including coughing, breathlessness, and fever. Its full pathogenesis remains unknown but individuals with certain underlying chronic conditions, the elderly and immunocompromised individuals are at greater risk (Guan et al. 2020).

The initial outbreak in Wuhan spread rapidly, affecting other parts of China. Cases were soon detected in several other countries. Outbreaks and clusters of the disease have been observed in Asia, Europe, Australia, Africa and the Americas.

On March 19 World Health Organization (WHO) declare the pandemic situation. The pressure on the health care system is very high in several countries and increasing numbers of infected health care staff are being reported. Many european countries have imposed major restrictions on meetings, travel and everyday life.

Spain has been one of the first countries dealing with the outbreak of COVID-19 and severe measures have been adopted to limit viral transmission. The first Spanish case was detected in a German citizen in La Gomera island on January 31st. Thereafter, infected patient number have grown at an exponential rate spreading to all Spanish regions, becoming one of the most affected countries in the world. Drastic emergency restrictions including quarantine and strict selfisolation measures were established.
Human tissues for transplantation represent one of the best treatment alternatives in many clinical circumstances. Maintaining their activity, ensuring their safety, should represent a goal for Health Services.

Although there is no evidence, recommendations concerning the screening of donors of human tissue and cells have been released as the potential for transmission of COVID-19 through transplant.

The US Food and Drug Administration has suggested considering a donors' history of travel to areas of outbreak, cohabitation with infected individuals, or diagnosis or suspicion of COVID-19 within the 28 days before recovery of donor tissue. Similar measures have been taken by the Global Alliance of Eye Bank Association and by the Joint United Kingdom Blood Transfusion Service Professional Advisory Committee to rule out potential donor. The European Society for Blood and Marrow Transplantation has recommended excluding potential donors who have been diagnosed with COVID-19 and waiting at least 21 days before donation in those with a history of high-risk travel or contact. In Italy, the National Transplant Centre recommended testing all potential tissue and stem cell living donors, as well as dead donors through real time RT-PCR assays of nasopharyngeal swab sample or broch alveolar lavage in deceased individuals.

In Spain, the National Transplant Organization (ONT) has taken stronger measures. From March 17, a systematic COVID-19 surveillance was imposed for deceased donors. Since then, all potential tissue donors are screened by SARS-CoV-2. In addition to this in April 24, that screening expands to potential tissue recipient patients.

Despite the efforts of the health authorities in maintaining this activity by ensuring the safety of the tissues, it is likely that we are experiencing a tremendous impact on the tissue transplant activity in Europe as many others parts of the world. The medium or long-term effects on patients requiring tissues for transplant, such as their impairment, as well the increased waiting lists, are unknown.

The aim of this study has been the evaluation of the possible impact on the activity of procurement and distribution of tissues during the peak period of the pandemic in Spain. For this study, a multicentre analysis has been made with a survey of some tissue 
banks in Spain, between first of March to 30th of April 2020.

\section{Materials and methods}

We have set up a survey of tissue activity during the period of March to April 2020 in Spain. This period was chosen for being the maximum peak of the pandemic in Spain.

Banks were asked for the number of donor, tissue processing and tissue distributed in comparison with the same period in the years 2017-2019.

Participants Tissue Establishments are included in Table 1. The number of participants is a representative sample of the tissue banks in Spain, which traditionally process and distribute a significant amount of tissue in this country.

\section{Statistical analysis}

Correlation and linear regression were used as techniques for quantifying the association between the two numeric variables: Prevalence of infection in each region as independent variable and donor declined percentage as response variable. We calculate Pearson's correlation (r) and Spearman's rho ( $\rho)$ coefficients. The hypothesis test of correlation tests were consider with a linear relationship with a $P<0.05$.

\section{Results}

Results are shown on Tables 2 and 3.

During the period between 1st March to 30th April 2020 we have observed a general drop in the number of tissue donors that ranged from $33,3 \%$ in the Navarra Community to $78,8 \%$ in the Basque Country, compared with the average number of tissue donors in the same period three years before. The average drop in number of donors has been from $55,8 \%$ in the Banks consulted.

Although there is a generalized drop in activity, very important differences between territories are appreciated. Basque Country, Aragon and Andalusia have increased bone production, with Aragon and the Basque Country also being the most demanded in the request for corneas. It highlights that the need for skin has been increased in the Valencian Community.

In general, tissue distribution has been greatly reduced because of the drop in surgical activity during the most important period of the pandemic.

\section{Discussion}

Countries around the world are mobilizing to try to halt the coronavirus outbreak that has infected more than 3 million people and killed more than 250.000 others. Spain has been a country especially affected in number of cases by infection. On April 30, 239.639

Table 1 Tissue establihsments (TE) participants and prevalence of COVID-19 at April 30, 2020. Source: Instituto de Salud Carlos III. Spain

\begin{tabular}{|c|c|c|c|}
\hline Region & $\begin{array}{l}\text { EU TE } \\
\text { code }\end{array}$ & TE name & $\begin{array}{l}\text { Prevalence COVID-19 } \\
\text { positive }^{\mathrm{a}}\end{array}$ \\
\hline \multirow[t]{2}{*}{ Andalusia } & ES000281 & $\begin{array}{l}\text { Centro Regional de Transfusión Sanguínea y Banco Sectorial de } \\
\text { Tejidos de Córdoba }\end{array}$ & 152 \\
\hline & ES000635 & $\begin{array}{l}\text { Centro Regional de Transfusión Sanguínea y Banco Sectorial de } \\
\text { Tejidos de Málaga }\end{array}$ & \\
\hline Basque Country & ES000091 & Centro Vasco de Transfusión Sanguínea y Tejidos humanos & 640 \\
\hline $\begin{array}{l}\text { Valencian } \\
\text { Community }\end{array}$ & ES001219 & Centro de Transfusión de la Comunidad Valenciana. Valencia & 222 \\
\hline Aragon & ES001309 & Banco de Sangre y Tejidos de Aragón. Zaragoza & 408 \\
\hline Madrid & ES000377 & Hospital Universitario de Getafe & 938 \\
\hline Asturias & ES000791 & Centro Comunitario de Sangre y Tejidos del Principado de Asturias & 249 \\
\hline Navarra & ES008180 & Banco de Sangre y Tejidos de Navarra. Pamplona & 806 \\
\hline
\end{tabular}

${ }^{\mathrm{a}}$ Number of cases $\times 10^{5}$ people 
Table 2 Number of donors received for tissue processing in Spain during the period of March 1 to April 30, 2020, compared to the average number performed in the same time fame of the last 3 years (2017-2019)

\begin{tabular}{llll}
\hline & $\begin{array}{l}2020 \\
(\text { March 1-April 30) }\end{array}$ & $\begin{array}{l}\text { 2017-2019 } \\
\text { (March 1-April 30) }\end{array}$ & \% variation \\
\hline Andalusia & 17 & 49.6 & -34.27 \\
Basque Country & 7 & 33 & -78.8 \\
Valencia Community & 5 & 14.6 & -65.8 \\
Aragon & 2 & 5.3 & -62.3 \\
Madrid (Getafe) & 1 & 2.3 & -56.5 \\
Asturias & 8 & 20 & -60 \\
Navarra & 4 & 6 & -33.3 \\
\hline
\end{tabular}

patients were diagnosed in Spain, the second country in the world after US with 1.053.036 (Johns Hopkins University and Medicine). Spanish government made strict confinement measures accompanied by a range of social distancing measures, including closure of schools, universities, libraries, centres for older people, and sporting venues, and even restricting all movement that have been in place since March 14 (royal decree 463/2020 to declare a 15-day national emergency). However, from March to 14 April, the death rate in Spain was $68 \%$ higher than usual and 21,882 excess deaths occurred. Coronavirus patients were overwhelming Madrid area.

The Spanish National Health System was decentralised since 2002. Coordination is crucial in any country, but especially in Spain in which responsibility for health is assigned to 17 very diverse regions. The Health Alert and Emergency Coordination Centre (Centro de Coordinación de Alertas y Emergencias Sanitarias in Spain), created in 2004, provides a mechanism for coordination between the national and regional governments and made the direction measures during the pandemic period.

Organizational and logistical aspects are required for transplantation activities including organ, tissue and cells an activity that is very sensitive to external factors. Spanish National Transplant Organization (ONT) has made many efforts in maintaining transplantation activity by ensuring the safety of the tissues. As the Euro CDC stated "Maintaining a safe, suffcient and accessible supply of critical and essential Substances of Human Origen (SoHO) during a pandemic is of vital interest to public health. It is therefore critical that $\mathrm{SoHO}$ establishments recognise the potential impact of the pandemic on the safe and sufficient supply of SoHO and adequately respond to ensure the maintenance of core services".
Although the impact of the pandemic on organ activity has been previously analysed (Angelico et al. 2020) so far less data is known regarding the impact on tissue activity.

Spain a country with a strong structure in the field of donation and transplantation show, on basis our results, a clear drop in the number of tissue donors obtained in the period from March 1 to April 30. We have not found differences between the drop in the number of donors and the greater or less involvement of the region by the coronavirus (Rho Spearman $-0.142 \mathrm{p} \mathrm{0.75) \text {. }}$

Multiple factors have been able to motivate it but, as very important, a restriction in the number of Intensive Care Units (ICU) beds available for donors may influence overall donation activity similarly to what has been published regarding organ donation (Angelico et al. 2020). ICU in many Spanish regions were over $80 \%$ capacity, despite efforts to triple the number of beds available. This drop of tissue donors ranged in our study between $33,3 \%$ in Navarra to 78 , $8 \%$ in the Basque Country.

On the contrary, tissue-processing activity has continued, although at more slowly pace in Spanish TE given the circumstance that the number of units of processed bone has been increased in the TE of Basque Country, Andalusia and Aragon with respect to the average of units obtained in the same period in the previous 3 years.

Many tissues can be stored during long period and thanks to the existence of stock in them, it has been possible to answer the urgent demand that has occurred in this period such as vessels and skin. In addition to this possible tissue, scarcities have been largely mitigated by a slow in demand due to the cancellation of elective operations. Only urgent 
Table 3 Comparison of units produced and distributed from Tissue Banks in Spain during March 1 to April 30, 2020, compared to the average number performed in the same time fame of the last 3 years (2017-2019)

\begin{tabular}{|c|c|c|c|c|c|c|}
\hline & \multicolumn{2}{|c|}{$\begin{array}{l}2020 \\
\text { (March 1-April 30) }\end{array}$} & \multicolumn{2}{|c|}{$\begin{array}{l}\text { 2017-2019 } \\
\text { (March 1-April 30) }\end{array}$} & \multicolumn{2}{|l|}{$\%$ variation } \\
\hline & Units produced & $\begin{array}{l}\text { Units } \\
\text { distributed }\end{array}$ & Units produced & $\begin{array}{l}\text { Units } \\
\text { distributed }\end{array}$ & Units produced & $\begin{array}{l}\text { Units } \\
\text { distributed }\end{array}$ \\
\hline \multicolumn{7}{|l|}{ Bone } \\
\hline Andalusia & 959 & 330 & 886.6 & 1024 & +8 & -67.8 \\
\hline Basque Country & 227 & 63 & 116 & 234.3 & +95 & -73.1 \\
\hline $\begin{array}{l}\text { Valencian } \\
\text { Community }\end{array}$ & 68 & 72 & 147 & 165.7 & -53.7 & -56.54 \\
\hline Aragón & 60 & 18 & 50.3 & 77.3 & +19 & -76.7 \\
\hline Madrid (Getafe) & 20 & 21 & 55 & 52 & -63.6 & -59.6 \\
\hline Asturias & 23 & 64 & 131 & 127.7 & -82.4 & -49.8 \\
\hline Navarra & 16 & 12 & 38.3 & 53.7 & -58.2 & -77.7 \\
\hline \multicolumn{7}{|l|}{ Cornea } \\
\hline Andalusia & 42 & 29 & 104 & 89 & -59.6 & -67.4 \\
\hline Basque Country & 14 & 22 & 47 & 36.3 & -70.2 & -39.3 \\
\hline Aragón & 4 & 10 & 10.6 & 12.3 & -62.3 & -18.7 \\
\hline Madrid (Getafe) & 2 & 2 & 1.3 & 1.3 & +53 & +53 \\
\hline Asturias & 12 & 5 & 28 & 24 & -57.1 & -79.2 \\
\hline Navarra & 8 & 4 & 12 & 10.3 & -33.3 & -61.2 \\
\hline \multicolumn{7}{|l|}{ Valves } \\
\hline Andalusia & 42 & 29 & 104 & 89 & -59.6 & -67.4 \\
\hline $\begin{array}{l}\text { Valencian } \\
\text { Community }\end{array}$ & 2 & 0 & 3.3 & 1.6 & -39.3 & -100 \\
\hline \multicolumn{7}{|l|}{ Vessels } \\
\hline Andalusía & 0 & 3 & 3.7 & 6.3 & -100 & -52.4 \\
\hline $\begin{array}{l}\text { Valencian } \\
\text { Community }\end{array}$ & 4 & 1 & 10.7 & 7.3 & -62.6 & -86.3 \\
\hline Asturias & 0 & 4 & 7 & 5.7 & -100 & -29.8 \\
\hline \multicolumn{7}{|l|}{ Skin $\left(\mathrm{cm}^{2}\right)$} \\
\hline Andalusía & 2014 & 5692 & 10.617 & 22.737 & -81 & -74.9 \\
\hline Valencin Community & 1514 & 3281 & 26.266 & 3.059 & -94.2 & +7.2 \\
\hline Madrid (Getafe) & 2000 & 3500 & 18.000 & 8.583 & -88.8 & -59.2 \\
\hline
\end{tabular}

surgical interventions or medical procedures have required the use of tissue.

Cornea due to the impossibility of long-term preservation is a critical tissue. Many corneal transplant has been cancelled or postponed in Spain with the increase in the waiting list of patients. Our results shown a drop of $79,2 \%$ in Asturias or $67,4 \%$ in Andalusia compared to average transplant in the here years before. Solutions to solve the shortage of supply of cornea and treatment need to be addressed soon.
In conclusion, our data suggest that the impact of coronavirus in Spain has affected dramatically tissue donation but with a moderate effect on stored tissues such as bone, valves or skin.

To date there is no available vaccine against SARSCoV-2 infections and no drug with proven clinical efficacy, although there are several candidates that might be effective in prevention or treatment. With more countries, planning to loosing restrictions imposed, many scientific concerned about the 
potential for a resurgence of a second wave. Tissue banks should prepare if next pandemic waves surges so that tissue provision is guaranteed both in urgent and elective surgeries.

\section{Bias}

Much of the tissue donation activity is concentrated in the first 15 days of March.

Banks such as Madrid (Getafe) present aberrant results because of their reduced processing activity.

Authors' contribution All authors were involved in the final approval of the article submitted and are in agreement with all the content. All the authors have participated in the design, methodology and collected data for the study.

\section{Compliance with ethical standards}

Human and animal rights This article does not contain any studies with human participants or animals performed by any of the authors.

Conflict of interest The authors declare that they have no conflict of interest.

\section{References}

Angelico R, Trapani S, Manzia TM et al (2020) The COVID-19 outbreak in Italy: initial implications for organ transplantation programs. Am J Transplant. https://doi.org/10.1111/ ajt.15904

Chen N, Zhou M, Dong X et al (2020) Epidemiological and clinical charasteristics of 99 cases of 2019 novel coronavirus pneumonia in Wuhan, China: a descriptive study. Lancet 395:507-513

European Centre for Disease Prevention and Control (2020) Novel coronavirus disease 2019 (COVID-19) pandemic: increased transmission in the EU/EEA and the UK—-sixth update. https://www.ecdc.europa.eu/sites/default/files/ documents/RRA-sixth-update-Outbreak-of-novelcoronavirusdisease-2019-COVID-19.pdf

European Centre for Disease Prevention and Control. Coronavirus disease-2019 (COVID-19) and supply of substances of human origin in EU/EEA-first update. https:// www.ecdc.europa.eu/sites/default/files/documents/ COVID\%2019-supply-substances-human-origin-firstupdate.pdf

European Society for Blood and Marrow Transplantation. Coronavirus disease COVID-19: updated EBMT recommendations 2020. https://www.ebmt.org/ebmt/news/ebmtrecommendation-coronavirus-disease-covid-19

Global Alliance of Eye Bank Association (2020) ALERT coronavirus (COVID-2019) and ocular tissue donation. February 3, 2020. https://www.gaeba.org/2020/alertcoronavirus-2019-ncov-and-ocular-tissue-donation/

Guan W, Ni Z, Hu Y et al (2020) Clinical characteristics of coronavirus disease 2019 in China. N Engl J Med. https:// doi.org/10.1056/NEJMoa2002032

Instituto de Salud Carlos III. Evolución pandemia. https:// cnecovid.isciii.es/covid19/\#declaraci\%C3\%B3n-agregada

Johns Hopkins University and Medicine. Coronavirus Resource Center. https://coronavirus.jhu.edu/map.html

Spanish National Transplant Organization (2020) COVID-19: impact on donation and transplant activity. [22 April 2020]. http://www.ont.es/infesp/Paginas/Impacto_tx.aspx

US Food and Drug Administration (2020) Important information for human cell, tissue, or cellular or tissue based product (HCT/P) establishments regarding the 2019 novel coronavirus outbreak. 14 February, 2020. https://www.fda. gov/vaccines-blood-biologics/safety-availabilitybiologics/important-information-human-cell-tissue-orcellular-or-tissue-based-product-hctp-establishments

Zhou P, Yang X-L, Wang X-G et al (2020) A pneumonia outbreak associated with a new coronavirus of probable bat origin. Nature 579:270-273

Zhun N, Zhang D, Wang W et al (2020) A novel coronavirus from patients with pneumonia in China. $\mathrm{N}$ Engl $\mathrm{J}$ Med 382:727-733

Publisher's Note Springer Nature remains neutral with regard to jurisdictional claims in published maps and institutional affiliations. 